\title{
Enduring Legacy: A Trail Of Doctrinal Uniqueness and Unity of the Evangelical Church Winning ALL (ECWA).
}

\author{
Mipo E. Dadang PhD* \\ ECWA Theological Seminary, Jos
}

*Corresponding Author: Mipo E. Dadang PhD, ECWA Theological Seminary, Jos

\begin{abstract}
Many nuances of doctrinal beliefs and practices appear to remain in the background of how things are conceptualized and applied within ECWA circles, however, quite often the details are not very familiar or thoroughly discussed with members and even some pastors who might not have had adequate theological training from evangelical seminaries. Hence, this work provides an important springboard of discussing some doctrinal statements that may not be on the basis of Biblical theology, specifically since doctrinal beliefs and practices usually inform many things within church denominations. Notwithstanding, issues such as religious heritage, doctrinal beliefs and practices and history were not explained fully in this article. However, the article begins with a brief historical outline of the beginnings of ECWA. It then briefly discusses the doctrinal beliefs and practice of ECWA in relation to the Bible, God, Jesus, Holy Spirit, angels, salvation, assurance of eternal faith, sanctification, church, ordinances, Christian life and service, spiritual gifts, blessed hope, the day of the Lord, and resurrection of the body. The article culminates with two challenges that ECWA is currently facing with its local church pastors concerning issues like the omission of the Apostles 'Creed in worship services and the negligence of youth ministry in churches which are at the verge of collapse. The article then proposes a guide towards making corrections in order for ECWA to return to her former practices that were deeply rooted in scripture before it becomes too late. The principles shared in this article, though specifically about ECWA, however, can be generally useful to other church denominations that desire to remain faithful to their history and biblical legacies.
\end{abstract}

Key words: Nigeria, ECWA, history, doctrine, religion, theology, leadership

\section{INTRODUCTION}

Right theological perspectives and practices are built on a reliable foundation drawn from correct legacies and documented information about doctrinal beliefs inherited in the Christian faith. This is true of denominations that desire to remain faithful to their history and legacies. Scholars, leaders, pastors and members of ECWA who desire a basic understanding of the discussion on the enduring legacy of a trail of the doctrinal uniqueness and unity of Christian faith and practice in ECWA, will want to pay attention to this piece. Hence, it is necessary to understudy the basics of Christian theology in the context of ECWA's belief and practice, especially since all believers in ECWA adhere to the doctrinal beliefs and practices of ECWA, because it is the doctrinal backgrounds that differentiate them from what other adherents of the Christian faith outside of ECWA.

Many nuances of doctrinal beliefs and practices appear to remain in the background of how they are conceptualized and applied within ECWA circles, and quite often these details are not very familiar to ECWA members and even some pastors who might not have had adequate theological training from evangelical seminaries. Hence, this article is necessary to as it seeks to provide an accurate doctrinal belief in the Christian faith drawn from scripture. This work provides an important complement in comparison to other doctrinal statements that may not be on the basis of Biblical theology, specifically since doctrinal beliefs and practices usually inform other practice in different denominations. Reading the piece would be helpful in scholarship and for the spirituality of all.

The article begins with a brief historical outline of the beginnings of ECWA. It then briefly discuss the doctrinal beliefs and practices of ECWA in relation to the: Bible, God, Jesus, Holy Spirit, angels, salvation, assurance of eternal faith, sanctification, church, ordinances, Christian life and service, spiritual gifts, blessed hope, the day of the Lord, and resurrection of the body. The article culminates 
with two challenges that ECWA is currently facing with its local church pastors concerning issues like the omission of the Apostles ' Creed in worship services and the negligence of youth ministry in churches which are at the verge of collapse. A suggestion is then made to serve as a guide towards making corrections and for ECWA return to her former practices before it becomes too late.

\section{BRIEF HISTORICAL BEGINNING OF ECWA}

ECWA is one of the largest church denominations in Nigeria, with international spread to other African countries, the United States of America, United Kingdom, and Israel reaching about ten million people. ECWA is a partner church of the international Christian Mission Organization: Serving In Mission. (SIM, formerly Sudan Interior Mission). It was founded in 1954 when the SIM-related churches came together to form one indigenous body. Since that time, mission stations, Bible Schools, academic schools, and medical programs have been transferred to ECWA leadership. Thus far, ECWA has experienced an exponential growth in membership, scope and leadership. Musa (2007:1) notes that "ECWA currently estimates her membership to be over six million in Nigeria. As a result of its numerical growth, the name was changed to Evangelical Church Winning All (ECWA) in the year 2010.

The Evangelical Church Winning All Constitution was revised and approved in April 2019 to reflect global practices. Baba (2019:16) affirms that "the missionary journey which started like a lifeless project had metamorphosed into a historical breakthrough that had over 10 million members in Nigeria alone and some 10,000 pastors of local gatherings of believers associated with the Evangelical Church Winning All in Nigeria”. Baba(2019:16), further asserts that apart from membership growth, "Serving in Mission missionaries are no longer the dominant figure in the life of the African church however, the enduring legacy SIM missionaries left has been its partnership relationship with the national church."

ECWA exists to glorify God. Believers and their beliefs and practices in ECWA are identified as evangelical and conservative in their doctrinal affirmation. ECWA is an upshot of evangelicalism and as Palmer (2015:173), notes, "African evangelicalism in its ideal form is wholistic. It is concerned with both our spiritual salvation and our present physical needs." Palmer (2015:173), further affirms that "African evangelicalism believes that God will meet our personal needs. It believes in God's power to supply our physical needs." Evangelical as the name of ECWA suggests is always employed to represent the emphasis on evangelization by converting non-believers to faith in Jesus Christ. As an evangelical church, ECWA stresses the importance of her core beliefs which require conversion of both nominal Christians and unbelievers to personal salvation in Christ. It is further a requirement that Christians witness their faith to evangelize non-believers. The doctrinal concepts of ECWA capture it adequately.

\section{BACKGROUND TO ECWA'S DOCTRINAL CONCEPTS}

Theology is the science of God and the relations between God and the universe. Cook (1987:12) explains that "theology is the collecting, ordering, comparing, exhibiting and defending of all facts from general and special revelation concerning God and the relations between God and the universe." Theology is a function of the Christian faith and scholarly scientific labor within the church. This is why Brown (2015:1, 2, 3, 4), notes that "doctrine guides us to true faith and godly life. Whereas theology in a more abstract sense is working out of true the implications of the true faith and godly life."

Theology therefore refers to human reflections on who God is, and his dealings in the world. Revelation is the basis of theology. God's word which is the Bible has its source from God and therefore is the most important tool for studying the Christian life and theology. Protestant Christians have similarities in their religious beliefs and practices. They worship a monotheistic God, manifested in Trinitarian form; they maintain belief that all humans are sinners saved from their sin only by the grace of God through Jesus Christ, they profess that the Bible is God's Word; they regard worship and prayer as important; they share in the ordinance practices and they attempt to lead ethical lives. This is what ECWA believes. The following summary of specific points offers an introductory work, but 
Enduring Legacy: A Trail Of Doctrinal Uniqueness and Unity of the Evangelical Church Winning ALL (ECWA).

does not intend to exhaust these core doctrinal beliefs and practices of ECWA. This begins with the authority of the Bible.

\subsection{The Authority of the Bible}

Like other protestant Christians who believe in the Bible, ECWA believes in the authority of the Bible through which God has revealed himself. The Bible is not only a revelation from God, but an infallible record of that revelation. ECWA Constitution (2019:4), upholds that "the sixty books of both the Old and New Testaments are the inspired Word of God, without error, in the words of the original writings... Paul affirms that "all Scripture is God-breathed." ( 2 Timothy 3:16). It is the supreme code of ethics. In deed the Bible comes from the infinite God and thus is a united book.

\subsubsection{Unity of the Bible}

The Bible is a unique divine revelation in the sense that although it was written by many different authors, over a period of 1600 years, it is one book. It has one doctrine, and system, one moral standard, one plan of salvation, and one program of all the ages. Peter one of the New Testament apostles affirms this by speaking in the affirmative of this prophetic utterances when he declares of the Old Testament prophets that "men moved by the Holy Spirit spoke from God"(1 Peter 1:21). Apart from the unity of the Bible, its claims are reliable. Metzger (1987:288), affirms that "the manner in which God's Word is contained in Scripture must not be envisioned statically, as a material content, but dynamically as a spiritual charge." It has been established that the Scripture is the embodiment of the divine revelation. The record of the revelation is genuine, credible and the only qualified vehicle that conveys that revelation. Erikson (2013:122), notes that general revelation is God's communication of himself to all persons, at all times, and in all places." Erickson (2013:144), further explains that "special revelation is God's manifestation of himself to particular persons at definite times and places, enabling those persons to enter into a relationship with him." So God's Word is inspired.

Inspiration deals with the recording of the revealed truth. There cannot be revelation without inspiration as has been the case with godly people in the past. Biblical record affirms that John heard the seven thunders uttering their voices, but was not permitted to write what they said (Revelation 10:3ff). Erickson(2013:169) explains that "the inspiration of Scripture is that supernatural influence of the Holy Spirit on the Scripture writers that rendered their writings an accurate record of the revelation or that resulted in what they write actually being the Word of God." The Holy Spirit moved within men to write the sixty-six books of the Bible (Acts 1:16; Hebrews 10:15-17; 2 Peter 2:21). The Scripture is fully and verbally inspired because it is God-breathed (2 Timothy 3:16). It is binding on the human mind, conscience, will, and heart. The Scripture is not only inspired and authoritative but it is also inerrant in all that it affirms whether in historical, scientific material and doctrinal matters. Inerrancy extends to all of Scripture and is not limited to certain teachings of Scripture. Illumination is understood as how God who inspired men to write Scripture illuminates the minds of those who read it. Inspiration is affirmed only of the autographs of the Scripture. Thus, it is not of any of the versions, whether ancient or modern nor of Hebrew or Greek manuscripts in existence nor of critical texts known. Bancroft (1976:46) notes that "the verbal, plenary or full inspiration accords with the general teaching of the Scriptures." From a sound belief in the authority of the Bible, ECWA holds firmly the doctrinal position of the Triune God.

\subsection{Triune God}

Christians believe in God who is omnipresent. This God is also known as immanent within the world and transcendent beyond the world, human knowledge and experience. ECWA Constitution (2019:4) upholds that, "there is one God, the Creator and preserver of all things, infinite in being and perfection, Father, Son, and Holy Spirit who are co-equal and Co-eternal..." The Bible does not teach the Trinitarian formula of God, but teach that the Father, Son, and Holy Spirit is one God. Erickson (2013:309) notes that "there has always been Father, Son, and Holy Spirit and all of them have always been divine. There has never been any alteration in the nature of the Triune God." Dabney (2002:181), also notes that "God is one and that not only the Father, but the Son and the Holy Ghost are proper God." Chafer and Walvoord (1978:40) further explain that "the doctrine of the unity of the Godhead makes clear that they are not three separate gods, like three separate human beings." Chafer 
and Walvoord (1978:40) argue that "the true Christian faith is not Tritheism, a belief in three Gods." It means that in the uniqueness of the Godhead, there is no illustration or parallel in human experience. The Trinitarian doctrine has a central place in the Christian faith although the subject is beyond human comprehension and has no parallel in human experience. Chafer and Walvoord (1978:41) further state that "the doctrine should thus be accepted by faith on the basis of Scriptural revelation even if it is beyond human comprehension and definition." Douglas (1989:14) concurs that "he who would try to understand the Trinity fully will lose his mind. But he who would deny the Trinity will lose his soul." Kelly (1978:267) concludes that "the Godhead is one because the Father never acts independently of the Son, nor of the Holy Spirit." Thus, the Christological affirmation is part of ECWA's conviction.

\subsection{Christological Affirmation}

Non-believers and other human authorities ask: if Jesus is the Son of God and Christians serve and worship him as God, how can they claim to be serving one God? Throughout church history, there has been such controversies. ECWA is distinguished from those who do not accept the divinity and humanity of the Son of God. ECWA Constitution (2019:4) states that "Jesus Christ is very God and very Man having been conceived by the Holy Spirit and born of the Virgin Mary." Jesus Christ as very God and very Man was the position upheld ever since the early church, yet the person and work of Jesus Christ has remained a stumbling block to many throughout generations. Christological controversies date back to the time Jesus Christ was in the world, both the religious and government leaders were perplexed by the Son of God and Son of Man. Cairns (1981:133), notes that the question was "could Christ save man if he were a demigod, less than true God and of a similar or different essence from the Father as Eusebius and Arius respectfully asserted?" It is historically correct that from the Nicene Creed in the fourth century, to Chalcedon, to the reformation and after reformation confessions, Christ has been seen as unique. Athanasius (ca 295-373) became one of the chief exponents of what became the orthodox view. Cairns (1981:134) affirms that "at the council this young man insisted that Christ had existed from all eternity with the Father." The argument Athanasius proposed was that Jesus Christ is truly God and truly man; that he is not a symbol, a shadow, a reflection, a creature or an instrument of God. Jesus is God. Athanasius used the theological concept that the Son was begotten and not made. He stressed that idea that begotten was not to be understood in a technical sense but as something taking place from all eternity. Hermon $(1981: 69,70)$ notes that "this has come to be known as eternal generation of the Son."

Christological controversies did not culminate with his person and work. The historical debate on the atonement should not detain cotemporary Christians. It is adequate to indicate that the Substitutionary death of Christ for humanity everywhere and at every time is the position upheld by leaders, pastors and members under ECWA. What still poses a threat to Christian witness in Africa today is wrong usage of contextualization about the uniqueness of Jesus Christ. Palmer (2015:73), notes that in the context of Africa, "Christian theology often uses contextualized metaphors in its Christology to describe the functions of Jesus." One of such controversial considerations of Jesus in the context of Africa is the title given to Jesus as ancestor. Pobee (1978:94) asserts that Jesus is "the Great and Greatest Ancestor." Disagreeing with such consideration of a theological concept that views Jesus as an ancestor, Aben (2008:128) opines that "African Traditional religion does not associate the title ancestor of a deity." Aben (2008:129) further buttresses that ancestral belief "can be rightly said of deceased human persons, but it cannot be said of the living Son of God."

The exponents who place Jesus as ancestors have flown in their theological perspectives and have missed the point in believing the revelation of God's written and Living Word. Palmer (2015:78) rightly observes that "the church fathers knew that for Jesus to be a complete Saviour, he would have to be fully human and fully divine. Only a human being can make a sacrifice for other humans and only God can make sacrifice for all humanity."

Kato (1982:22) counsels that "Christians must hold to the uniqueness of the Christian revelation in the written Word and the Living Word." Kato (1982:22) further emphasises that "to seek salvation elsewhere than through the shed blood of Christ is heretical. It is the preaching of another gospel, which really is no gospel." Latourette (1975:50) concludes that "this uniqueness of Jesus and the 
revolutionary contrast of his teaching with the traditions of his people were the source of the much conflict which brought Jesus to his death."

Jesus affirmed that "I am the way the truth and the life. No one comes to the Father except through me" (John 14:6). Nicene's contribution to biblical theology lies in its grounding in the person of Jesus Christ. Nicene brought an awareness to the reality that without a clear focus on this historical Jesus, fully God and fully human. It is interesting to understand that wherever the Nicene faith developed strong roots, the church survived and flourished, despite the most violent forms of persecution. Anderson (1972:41) points out that Athanasius concluded his argument by saying that "if Christ is not the Son of God, the second Person of the Trinity incarnate, then our very salvation is lost, for no created being could redeem other creatures"

Gunton (1992:80) notes that, "the purpose of the incarnation is to prevent the good creation from failing to achieve its true destiny: that the Father's intent of love should not fail its purpose." Torrance (1981: xiii, xiv), notes that "throughout the apostolic tradition Jesus is presented as acting out an unbroken oneness between Himself and the Father." Athanasius, sound biblical-theological reasoning and application helped him stood firmly as a result of his courage and uncompromising character. The next theological affirmation of ECWA is its harmony on the doctrine of the Holy Spirit.

\subsection{The Holy Spirit}

From church history, the affirmation of the deity of the Holy Spirit was the culmination of the work begun by Athanasius. Kelly (1978:259), notes that "Athanasius secured acceptance of the proposition that the Spirit was not a creature but belonged to, and was inseparable from, the substance of the Father and the Son." Theological controversy on the Holy Spirit started in church history from the western and eastern churches. Harris (200: 495,496,497,498,499,501) notes that "while theological controversy continued to rage in the east, Christianity continued to expand. In the east, Christianity reached China through Nestorian missionaries." With regards to the person of the Holy Spirit, Kelly (1978:258) explains that the recognition of the full deity of the Holy Spirit was completed cautiously and circumspectly by the Cappadocian fathers." But there was a theological controversy concerning the procession of the Holy Spirit between the eastern and western churches. The main theological issue that sparked serious controversy involved the addition to the Nicene Creed of the phrase "and the Son" by western theologians. Dadang (2015:158) notes that "This is known as the filioque controversy as the concept of "double procession," that the Holy Spirit proceeds both from the Father and from the Son."

Cairns (1981:133) brings to light that "when the creed of Constantinople, the Nicene creed was recited at the third council of Toledo in 589, the words "and the Son" (filioque) were added to the statement that proceeded from the Father and the Son" (Cairns 1981:134). Cairns affirms that "the Western churches since then have insisted on the true deity of the Holy Spirit as coequal, coeternal, with the Father and the Son" (Cairns 1981:135). The Holy Spirit has been sent by the Father and the Son to indwell and guide believers. ECWA Constitution $(2019: 4,5)$ believes that "the Holy Spirit is third person of the Godhead and has abiding presence in a believer with a divine mark of ownership eternally." ECWA agrees that angels are created, spiritual beings with moral judgment and high intelligence, but without physical bodies (Col.1:16). ECWA Constitution (2019:5), states that "God originally created an innumerable company of spirit beings, known as angels who are massagers of God to help his people in all ages." ECWA Constitution (2019:5), upholds that, "Man was created in the image and likeness of God but in Adam all mankind fell into sin with the result that all men are sinners by nature and action. All men are depraved and without hope apart from Christ's work on the cross. Hoekema $(1986: 68,69,70,71,72,73)$, opines that "we are like God in structure and in function."

Therefore, human kind was created in a trio relationship: Adam and Eve were created in a good relationship with God, fellow human persons and with nature. Hoekema $(1986: 81,82)$ affirms that "originally, Adam and Eve lived in harmony with God, with each other and with creation." Humanity was created in a good relationship with God but sin corrupted the relationship. The assurance is that salvation in Christ restores this relationship. The doctrine of salvation is theologically called soteriology - salvation is the appropriation of the benefits of the work of Christ. ECWA 
Constitution2019:6) upholds that "Salvation is received by faith alone in the God-Man, Jesus Christ apart from works." Those who seek theological knowledge are those who understand through the Bible. By virtue of this saving grace, sinners who deserve the judgment of God are forgiven, justified and brought into a holy relationship with God and brought into the redeemed community, which is the context of theology.

\subsection{The Church}

Jesus said "I will build my church" (Matthew 16:18). The church of Christ has grown from a handful of disciples to what it is today. Those who seek the knowledge of theology must be part of this community of God's people. Eternal perspective is the hope of theology. Christian theology is concerned not just with the present but also with the future. The Bible provides hope of a future where there will be peace, righteousness and justice. This future hope is what ECWA believes to be the assurance and eternal security of all those who have faith in Christ. ECWA Constitution (2019: 6), states that, "everyone who truly believes in Jesus Christ's atoning work are eternally kept saved due to the abiding presence of the Holy Spirit unto the day of redemption." Hence for ECWA (2019:6), the sanctification or the believer's setting apart is "positional at the point of conversion, and progressive on a daily basis as we walk the Christian pilgrim way and ultimately which is experienced in the hereafter when each believer enters into the presence of the Lord." Ladd (197:537) notes that the church is defined as "the new people of God or the community of believers." The church as one, holy and apostolic. But Palmer (2015:124) notes that "it is regrettable that in history the church has often become unfaithful." Palmer (2015:125) argues that "a true church is one that will conform to the ideal of Scripture. A true church will have true doctrine and godly lifestyle." Boice $(1986: 576,585)$ equally alleges that a true church manifests, "joy, holiness, truth, mission, unity and love. If these marks are absent, a true church is certainly absent." However the ordinances are a means that unites believers.

\subsection{The Ordinances}

ECWA continues to keep the unity of believers to God through the regular observant of two ordinances, the Lord's Supper and water baptism by immersion. Cairns (1981:83), notes that "immersion seems to have been widely practiced in the first century church" adding that, "the Lord's supper and baptism were the two sacraments that the early church used because they had been instituted by Christ." Hastings (1999:127) observes that "the outward signs in baptism were the words invoking the name of the Father, the Son, and the Holy Ghost." According to ECWA Constitution (2019:7), "The ordinances of the church are the Lord's Supper and water baptism by immersion." ECWA's application of water baptism by immersion is in harmony with the example of Jesus' water baptism by immersion at the start of his earthly ministry (Matthew 3:13-16). Hastings (1999:127), states that "the inward reality was something which changed them for ever. It took away the guilt of their sinfulness, inherited from Adam and replaced it by membership of the church and a state of grace, a sharing in the life of God." Cairns (1981:84) opines that "only those who were baptised could partake in the communion." As baptized members, ECWA views the church as a group of believers who come together to worship God and support each other in their efforts to live fruitful Christian lives of service. Hence, ECWA (2019:7), believes that "the Holy spirit bestows diverse grace gifts upon all who believe in Christ for enablement of service for God's glory." Thus ECWA strongly believes in the blessed hope ECWA Constitution (2019:8) believes that "the blessed hope of the church is the personal imminent and premillennial coming of the Lord Jesus Christ which is the rapture of believers, both the living and the dead." ECWA expects that "this hope must have a vital bearing on the personal life and service of the believers." Concerning tribulation, ECWA (2019:8), believes that "in the end times shall come a period of divine judgement upon the whole world which, day after day, continues to ripen for judgement." However, with these sound doctrinal beliefs and practices in ECWA, the denomination has some challenges that bedevilled her. Prior to the COVID19 Pandemic, worship services within most English speaking ECWA churches lasted between ninety minutes and a hundred and twenty minutes.

In most ECWA English speaking churches, because of generational gap between the older and younger clergy, one important doctrinal practice of reciting the apostolic creed and Lord's Prayer in worship services has declined. This is so because there is a big generational gap between older clergy 
Enduring Legacy: A Trail Of Doctrinal Uniqueness and Unity of the Evangelical Church Winning ALL (ECWA).

and younger clergy in ECWA today. There is also a gap between youth and older members in ECWA. These gaps have bearings on the ethical lives of believers in ECWA.

\section{ECWA MEMbERS AND ETHICAL LIFE}

The key question to ask having examined the doctrinal beliefs of ECWA is, "How does ECWA's doctrinal beliefs translate into action in the lives of leaders and pastors that would also have impact on members?" The approach employed in discussing this section is very experiential and personal, particularly as one that has gained significant experience in church leadership at different levels, especially in ECWA. I have held position at the district level of ECWA and at apex level, serving as the General Secretary of ECWA for six years,

Foundationally to understanding the implication of doctrinal beliefs for the life of ECWA leaders, pastors and members is to look at it in the light of Jesus' teaching in the Gospels. He summaries the whole of the Law and the prophets in two commands, Love God and "love your neighbors as yourself" (Matthew 22:37-99). Mears (1960:418) notes that "the measure in which Christians love one another is the measure in which the world believes in them or their Christ." Thus, our doctrinal beliefs are made alive in the simple act of love. Let us examine the implication of this for the believer's paragon, fairness and missionary activity.

\subsection{Paragon}

Paragon refers to the concept that people serve God through their everyday work. West describes work as a divine assignment and this idea of work as God's assignment to human beings is from the Bible. West (1997:19) notes that "work then, is our divine assignment to develop our world on God's behalf." West (1997:19) fu1rther reiterates that "work was a divine assignment before work was ever viewed as a curse" West (1997:19), adds that "even in paradise of Eden, work was part of life and considered to be an assignment by God." Thus, work is simply perceived as an expected ordinary part of life. It is an integral part of the way life is that people work. (West1997:21). Virtually, labor can become an extension of Christian faith. The work of lawyers, nurses, doctors, and politicians has no greater spiritual value than that of carpenters, refuse collectors, and taxi drivers. What is important is their faithful exercise for the benefit of others. Thus, our work gives us the opportunity to practice the doctrinal beliefs we hold so dearly. Sider makes a comment about other wings of the evangelical's community who had their own ways of withdrawing from the rest of society. Sider therefore, notes that "we no longer withdraw from the main stream of society. We are doctors, nurses, and dentists, carpenters and plumbers, business leaders and professors, politicians and artists working right in the center of the country" (Sider 2003::63). Thus, the Christian concept of paragon is that every good work done faithfully serves God.

\subsection{Fairness}

Biblical injunction to love one's neighbor captures many ethical positions of believers in ECWA. As observed, this is a model that believers in ECWA and elsewhere seriously strive for, but usually fail to reach. Before the New Testament era, prophet Jeremiah called attention of leaders and shepherds in the Old Testament to fairness to people. Jeremiah challenged leaders stating that to know God is to do justice and righteousness and judge the cause of the poor and needy (Jeremiah 22:13-17). Scott $(1980: 64,65,66,67)$ opines that a "hunger for God does not throw us into pietism, but into the thick of injustice on this planet earth." Some people in pursue of righteousness, they belief withdrawal from the society will help. Does justice and righteous contradict each other? Miranda (1974:93) thinks that "justice and righteousness is a phrase similar in concept of social justice."

In the New Testament, the Gospels give account of Jesus' love for his neighbor and his concern for fairness. Perkins (2001:22) notes that "the essence of Christianity could be summed in two inseparable commandments: love God and love the neighbors." Jesus cares for the poor, the sick, and the outcasts of society. He speaks out against the political, social, economic circumstances that worsen their plight. Believers today are called to emulate Jesus. Believers are to be working to transform the world through love and advocacy for fairness since they themselves have been transformed by the love and forgiveness of God. Perkins (2001:22) affirms that believers' "love for 
Christ should break down every racial, ethnic, or economic barrier. The task of loving the poor is shared by the entire body of Christ, black and white, brown or yellow, rich or poor..."

Believers are required to respect the dignity of every human being by ensuring never to exploit people, groups or nations as a means to an end. Perkins (2001:22) notes that "when the body of Christ is visibly present and when they are loving their neighbors and their neighbor's family as themselves and their family, the result is redistribution." Because believers, like all people are not perfect, they do not usually live up to this loving benevolence so they are not always conscious to practice justice in their actions and behaviors. Yet they are obligated to always make attempts to practice it. These actions become ways which believers express their calling to serve God.

\subsection{Missionary Work}

A better word than calling to express a person's purpose to live out the Christian faith is one's service in mission. Believers are to be on mission in their various jobs either clergy or non-clergy. West adds that, "laypeople are to be much bit on mission in their secular jobs as professional clergy are to be in their work (Perkins 1997:31). Doing work as mission provides a way for connecting work with faith. The task of spreading the Gospel intertwines with Christians' paragon and fairness. Exercising a person's paragon and working toward fairness makes the Christian a model for non-believers.

However, there are certain declining issues today in ECWA. In this contemporary times, generational gap has led to a decline in application of certain practices such as the recitation of apostolic creed, which encapsulates the doctrinal belief of the church. Additionally, this can be linked to the fact that the youth in ECWA are not having the needed attention to prepare them for the future sustainability of the doctrinal beliefs and organization as a whole. The succeeding section will discuss these declining issues. ECWA has sustained a sound doctrinal position all through the years. But there are two defaults that need to be addressed. First, there is a decline in applying the apostolic creed in worship services

\section{The RECITATION OF APOSTOLIC CREED}

Virtually all English-speaking churches in contemporary ECWA congregations are no longer led in reciting the apostolic creed as enshrined in the ECWA membership card. This has happened as result of the reality that most of the congregations of ECWA are led by younger pastors who did not have opportunity to be mentored by older pastors who have retired. This decline has deemphasised the importance of the apostolic creed in the lives of members. Young generation pastors need to clearly define Christianity in Biblical terms, which the Apostles' Creed succinctly provides to believers. The Apostles' Creed is the most historic and universal summary of the Christian faith in the entire history of the church. It instructs, guides, defends and enshrines the most important question of all what must I do to be saved?

Today, in Nigeria, both evangelical and Pentecostal churches are in an age of mass spiritual confusion. Pastors in today's generation have become increasingly secular and confused on doctrinal matters in recent years. A progressive nominal life in the church has blurred the lives of members between reality and action. Some pastors and members alike seem to surrender the fundamental truths of their faith to miracle weekend conferences and superficial show hosts. Moher (2019:1, 2, 3, 4) reminds Bible believing believers that "the Creed reminds Christians of the central truths of their faith to clarify the Bible's revelations on Jesus Christ and the impact of Christ on our redemption." There is therefore, the need for the current generation pastors in ECWA to return to historic Christianity. The Apostles ' Creed summary is of a timeless Biblical truth which provides the church with the essence of the Christian belief throughout history as followers of Christ attempt to construct a Biblical worldview and theology based upon the teachings of the Bible. ECWA; leaders need to enforce the Apostles' Creed in all Churches.

\subsection{Youths in ECWA}

The second declining ministry in ECWA involves not giving attention to the youth ministry through proper guidance and mentoring so that they can take up leadership roles soon without intimidation. There is a dichotomy between youth and various church leadership structures and the pastoral pulpit ministry in ECWA in this twenty-first century. A survey and discussion with young people and youth leaders from 2018 to 2020 shows that youth in ECWA are very passionate and hopeful about ministry. 
There is optimism for an experience of real change in the lives of young people and in the church. However, this optimism and energy is often being tempered by the structure and rules of both the local church and the Nigerian society.

There is no doubt that young people in Church and in Nigeria are struggling with life, their faith and the church. Listening to the comments of several youths is rather pathetic. Youth are crying around ECWA churches in Jos, Plateau, Nigeria. The is a call for the organization from top to local church levels not to focus on form but focus on message and truth of scripture. There is too much focus on rituals and mere church days and weeks. The church does not give youth freedom to be themselves, but the outside walls of the church does. The restrictions and rigidness are pushing young people out of church. They youth are crying that leaders and local church pastors with pulpits need to get to know youth closely and the nature of their language. Youth want a chance to talk with older people without being judged. ECWA might lose young people to the world by holding on too rigidly to them. Rather than being flexible. Leaders and pastors within ECWA structures place too much focus on the small things rather than the big things. Young people are struggling with their spirituality. A pertinent question asked is "do leaders from the top to local church levels know what is happening with youth? Youth allege that some pastors are given positions because of training rather than passion. Youth cry that there is the need for leaders and pastors to be flexible and stop comparing youth. Leaders and pastors need to allow youth to make mistakes before correction (Talk show with youth at an ECWA Church 2020:31, July).

There are some barriers to seeing youth work develop beyond what it is today in ways that are relational to the emerging generations in both the church and Nigerian society. Most pastors in context of Nigeria and church do not differentiate between human traditions and Biblical values.

There are practical ways or examples if leaders and pastors in ECWA really desire to assist many of the youth in local churches. To reach young people there is need to get on their level which goes against the understanding of authority and respect that people grow up within Nigeria. To engage young people about their faith means pastors have to provide opportunities for them to interact about their faith in small groups where for so long the focus has been on getting young people to the big programmes. Young people learn about their faith and they start to own it when they can discuss and express their doubts and their faith journey. Some ECWA leaders and pastors think that for youth to express their doubts and struggles is seen as a sign of weakness. The youth in ECWA need to be heard and engaged. Acevedo (1989:21) passionately notes that "youth ministry is not an extravagant luxury that only big" churches can do. Wherever youth exist, the church must seek to win them to Christ and disciple them." Acevedo (1989:21) argues that "to fail to minister to youth is to ignore our Scriptural mandate to clear our eyes to the problems of today's young people." Additionally, Acevedo (1989:33) appeals that "the church needs to raise up a generation of young people who are grounded in God's Word, committed to his church and willing to serve a broken and lost world."

The church's hope and Nigeria society rests squarely in the laps of young people. The future of the church depends on transferring the faith to young people. The success of a youth ministry depends upon how willing leaders and pastors of ECWA participate in young peoples' lives and help them to become disciples of Jesus Christ. There is therefore need for a framework to help leaders, pastors and youth leaders in ECWA and Nigeria to mentor young people.

\subsubsection{Ways Forward for Youth Ministry in ECWA and Nigeria}

(1). Develop a separate identical transformational manual for youth ministry which addresses needs, defines worldview and life issues which are different for young people since there is now a recognised youth culture in Nigeria and in ECWA churches. On National, in 2019, the National Assembly, in recognition of the uniqueness of young people passed a bill for not too young to run for leadership positions in Nigeria. Which was a clear statement that young people are struggling for platforms. However, for ECWA, leaders at the top and pastors in local churches are to provide enabling relational environment for youth to have opportunities through which they can be developed and empowered. This is possible when ECWA leaders and pastors become intentional, relational and reproducible disciple makers of young people. Putman (2010:86) argues that "intentional leaders create an environment for growth." Putman (2010:93) further stresses that "a relational environment is 
Enduring Legacy: A Trail Of Doctrinal Uniqueness and Unity of the Evangelical Church Winning ALL (ECWA).

the vehicle best suited for discipleship. It allows strangers and acquaintances to become a discipleship family."

(2) Another tool that would help enhance youth ministry is to define youth age groups. For pastors in ECWA to meet the needs and life stage issues of young people means that there needs to be a change to what is seen as youth ministry today. People under 30 have very specific needs. It means it would be helpful to officially restrict 30 as the age limit. It would also be really helpful to come up with teenage and young adult care (13 to 18 and then 19-30 years). From pastoral and leadership experience, there are so many emotional, intellectual, spiritual and relationship differences between a 16-year-old and a 26-year-old. Thus, meeting the needs will help young people grow spiritually and personally.

(3). Over many years, youths function in ECWA as a committee. In this twenty first century and beyond, there is need to move youth from committee to ministry. Often committees provided a simply functional role rather than a ministry role. Thus, the focus of youth ministry should be on developing a team and disciples among young people. In ECWA the problem of youth seemed to have been compounded on the basis of creating Christian education organizers at the national, districts and local church councils. There are no churches in these levels but shared leadership structures. Rather than that, youth pastors should be considered in all ECWA Churches. The role of the youth pastors and how they fit into the existing local churches are to be defined. Creating a Christian education organizers has hindered and created a clash between youth pastors to fit into youth fellowships and committees. It needs to be considered that it is a clash between having a focus on programmes and having a focus on ministry. This has led to issues of accountability, reporting structures and conflict of roles. One is of the opinion that more work and understanding needs to be done on what structures are needed if youth pastors are going to be effective in ECWA churches. This calls for consistency in giving attention to youth in churches.

(4). There is need for consistent structured discipleship training for youth leaders who will in turn reproduce other youth in ECWA churches and in Africa. There has been an observation over time, of inconsistency in handling youth ministry in ECWA. In view of my many years of experience in ECWA, this issue is the biggest challenge to youth ministry. Youth leaders are hungry for discipleship training, support and encouragement in their roles, but they often receive little of any of these. Too often youth leaders are running the same type of programmes in the same way because they have not been given tools of reproducible disciple methods to be more effective and productive. If ECWA was able to develop an indigenous structured and consistent reproducible discipleship training for their youth leaders who will in turn reproduce other youth then this would have the most impact on youth ministry in ECWA churches where emerging leaders would be mentored into becoming leaders now and in the next millennium.

\section{Conclusion}

The main goal of this article has been to make known to the reader historical uniqueness and unity of doctrinal tenets of faith and practice in ECWA. More examination of these concepts are encouraged. In today's society where faith and practice are important in any religious setting, an important challenge for all Christians in ECWA and elsewhere is not to stop learning about upholding their doctrinal beliefs and practices which differentiate them from false religious beliefs. Meeting that challenge can be the certain path to remain in Christian faith without declining in some of its core beliefs and practices as currently is the case in among ECWA local church pastors who are neglecting issues of apostolic creed and empowering youth through reproducible discipleship that can excel the numerous youth in ECWA Churches to take up leadership roles now and in the next millennium.

\section{REFERENCES}

[1] Aben, T. (2008). African Christian Theology, African Christian Textbooks, Bukuru,

[2] Acevedo, J., and Goddard, H. (1989).The Heart of Youth Ministry: Building a Dynamic Youth Ministry from the Ground Up, Bristol Books, Wilmore, KY,

[3] Anderson, DP. (1972). Bible Doctrine, The Banner of Truth Trust, Britain,

[4] Bancroft, EH. (1976). Christian Theology: Systematic and Biblical, Second Revised Edition, Zondervan, Grand Rapids, MI, 
Enduring Legacy: A Trail Of Doctrinal Uniqueness and Unity of the Evangelical Church Winning ALL (ECWA).

[5] Berkhof, L. (2012). Systematic Theology, The Banner of Truth Trust, Edingburg,

[6] Boice, J.(2007). Foundations of the Christian Faith, Intervarsity Press, Downers Grove,

[7] Brown, J. (2015).Systematic Theology: A Compendious View of Natural Revealed Religion, Reformation Heritage Books, Haddington,

[8] Cairns, EE. (1981)., Christianity Through Centuries: A History of the Christian Church, Academie Books and Zondervan Publishing House, Grand Rapids, MI,

[9] Charfer, LS., and Walvoord JF. (1978).Major Bible Themes, Zondervan Publishing House, Grand Rapids, MI,

[10] Dabney, RL. (2002). Systematic Theology, The Banner of Truth Trust, Saint Louis,

[11] Dadang, ME. (2015).Standing Firm: An Able God for Disable People, Daveco Prints and Publishers, Jos, Nigeria,

[12] Douglas, A. (1989). One Hundred Bible Lessons, Gospel Literature Service, Bombay,

[13] Erickson, MJ. (2013).Systematic Theology Third Edition, Baker Academie, Grand Rapids, MI,

[14] Gunton, CE. (1992). Christ and Creation, William B. Eerdmans Publishing House, Grand Rapids, MI,

[15] Hastings, A. (1999).A World History of Christianity, William B. Eerdmans Publishing Company, Grand Rapids, MI, Cambridge, UK,

[16] Herman, A. (1981). The Incarnation: Ecumenical Studies in the Nicene Constantinopolitan Creed, Edited Thomas F. Torrance, The Handel Pres, Edinburg,

[17] Hoekema, A. (1986).Created in God's Image, Eerdmans, Grand Rapids, MI,

[18] Kato, BH. (1985).Biblical Christianity in Africa: Theological Perspectives in Africa, Africa Christian Press, Ghana,

[19] Kelly, JND. (1978). Early Christian Doctrines, HarperCollins Publishers, NY, NY,

[20] Ladd, GE. (1974). A Theology of the New Testament, Eerdmans, Grand Rapids, MI,

[21] LaTourette, KS. (1975). A History of Christianity Volume 1 to AD 1500, HarperCollins Publishers, SanFrancisco,

[22] Mears, HC. (1960). What the Bible Is All About, G/L Publications, Glendale, California,

[23] Miranda, JP. (1974).Marx and the Bible, translated, John Engleson, Orbis Books, Maryknoll,

[24] Moher, A. (2019), .The Apostles Creed: Discovering Authentic Christianity in an Age of Counterfeits, Thomas Nelson Books, Nashville, TN,

[25] Palmer, T. (2015).Christian Theology in an African Context, Africa Christian Textbooks, Bukuru, Nigeria,

[26] Paula, H. (2001).Global Missiology for the $21^{\text {st }}$ Century: The Iguassu Dialogue edited William D. Taylor, Baker Academic, Grand Rapids, MI,

[27] Perkins, JM. (2001). Restoring At-Risks Communities, Baker Books, Grand Rapids, MI,

[28] Pobee, J. (1979).Toward an African Theology, Abingdon Press, Nashville,

[29] Putman, J. (2010).Real-Life Discipleship Training Manual, Navpress, Colorado,

[30] Robert, CW. (1987). Notes on Systematic Theology, Western Conservative Baptist Seminary, Portland, Oregon,

[31] Scott, W. (1980). Bring Faith, Justice, Eerdmans Publishing House, Grand Rapids, MI

[32] Sider, RJ. (2003).Doing Evangelism Jesus' Way: How Christians Demonstrate the Good News, Evangel Publishing House, Nappanee, Indiana,

[33] Vauesikey, DJ. (2009)., We Believe: Therefore We Speak the Theology and Practice of Evangelism, Northeastern Publishing House, Milwaukee, Wisconsin,

[34] West, R. (1997).Go to Work and Take Your Faith Too! Peake Road, Macon, Georgia, Magazine and bulletins

[35] Baba, S.P., (2019).The Current ECWA President of the Evangelical Church Winning All (ECWA)). Full of Appraisal; at SIM'S 125 anniversary celebration, Held in Jos.

[36] Baba, S.P., (2019). ECWA Membership Card, ECWA Productions Ltd, Jos, Nigeria,

[37] Peter, S.A., (2019.Constitution of the Evangelical Church Winning All(ECWA) As Amended, Challenge Press, Jos, Nigeria, 


\section{AUTHORS' BIOGRAPHY}

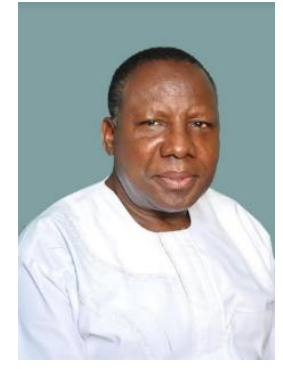

Rev. Dr. Mipo E. Dadang, Ph.D has extensive experience in church leadership and theological education holding senior church posts within the ECWA denomination at district level, and latterly as General Secretary of ECWA for six years. Internationally, he set up and led and led Africa Services, a non-profitable organization. He was first West Africa Director for Community Bible Study International (CBSI). After theological training in Nigeria and at Eastern University Palmer Theological Seminary in Philadelphia he completed a Ph.D. from Concordia Theological Seminary, Fort Wayne, Indiana. Married with four children he is currently a full time faculty at ECWA Theological Seminary Jos (JETS). Has travelled to different parts of the world: USA, South Africa, Ethiopia, Egypt, Nairobi, Europe, Ghana, Abidjan, Hawaii, where he attended Haggai Leadership Institute and the Middle East.

Citation: Mipo E. Dadang PhD. "Enduring Legacy: A Trail Of Doctrinal Uniqueness and Unity of the Evangelical Church Winning ALL (ECWA)." International Journal of Humanities Social Sciences and Education (IJHSSE), vol 7, no. 10, 2020, pp. 16-27. doi: https://doi.org/10.20431/2349-0381.0710002.

Copyright: () 2020 Authors. This is an open-access article distributed under the terms of the Creative Commons Attribution License, which permits unrestricted use, distribution, and reproduction in any medium, provided the original author and source are credited. 